\title{
СОЦИОДЕМОГРАФИЧЕСКИЕ ИССЛЕДОВАНИЯ
}

\author{
DOI: 10.15838/sa.2021.5.32.1 \\ УДК 314.8, 316.6 | ББК 60.74 \\ (C) Шабунова А.А., Калачикова О.Н., Короленко А.В. \\ ДЕМОГРАФИЧЕСКИЕ ИТОГИ 2020 ГОДА: \\ СТАТИСТИЧЕСКИЕ АРТЕФАКТЫ И СОЦИАЛЬНЫЕ \\ ПАРАДОКСЫ ПАНДЕМИИ
}

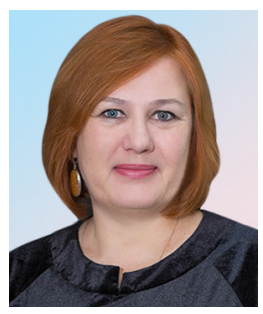

\section{АЛЕКСАНДРА АНАТОЛЬЕВНА ШАБУНОВА}

Вологодский научный центр Российской академии наук

г. Вологда, Российская Федерация

e-mail: aas@volnc.ru

ORCID: 0000-0002-3467-0921; ResearcherID: E-5968-2012

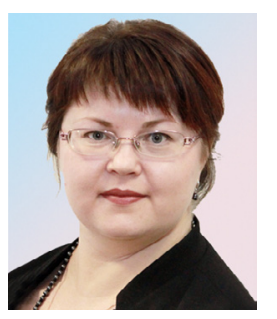

\section{ОЛЬГА НИКОЛАЕВНА КАЛАЧИКОВА}

Вологодский научный центр Российской академии наук

г. Вологда, Российская Федерация

e-mail: onk82@yandex.ru

ORCID: 0000-0003-4681-4344; ResearcherID: I-9562-2016

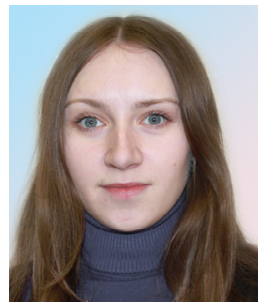

\section{АЛЕКСАНДРА ВЛАДИМИРОВНА КОРОЛЕНКО}

Вологодский научный центр Российской академии наук

г. Вологда, Российская Федерация

e-mail: coretra@yandex.ru

ORCID: 0000-0002-7699-0181; ResearcherID: I-8201-2016

В работе представлен анализ основных демографических показателей, зафиксированных в России по итогам 2020 года. Выявлено, что пандемия вируса COVID-19 способствовала закреплению наметившегося тренда снижения рождаемости и росту смертности населения. Вклад коронавируса в структуру смертности составил 7\%, что выше процента смертности от болезней органов дыхания, пищеварения, инфекционных заболеваний и сопоставимо с долей смертности от внешних причин даже по структуре 2019 года, в которую коронавирус не входил. Ожидаемая продолжительность жизни сократилась на 1,8 года, причем сокращение у женщин более выражено, чем у мужчин, что несколько сгладило гендерную диспропорцию общей продолжительности жизни. 
Статистическим артефактом является фиксируемое снижение заболеваемости населения. Очевидно, что в условиях пандемии следует осторожно относиться к этому показателю ввиду снижения выявляемости заболеваний, сочетанности диагнозов с COVID-19. Это же относится и к оценке структуры смертности, в которой 100\% стало распределяться на большее число причин, хотя коронавирус должен войти в класс инфекционных и паразитарных болезней, что требует переосмысления концепции эпидемиологического перехода. В условиях пандемии население показало некоторую склонность к деструкции в самосохранительном поведении. В частности, сократилась доля придерживающихся умеренности в приеме алкоголя, который часто принимается как средство от стресса. В то же время большинство выполняет рекомендованные и регламентированные меры: ношение масок, перчаток, соблюдение дистанции, санитарной обработки. Антипрививочные настроения отчасти обусловлены недостаточно полной и противоречивой информационной кампанией относительно вакцинации, активными вбросами фейковой информации.

Пандемия COVID-19, коронавирус, вакцинация, заболеваемость, население, самосохранительное поведение.

\section{Введение}

Пандемия новой коронавирусной инфекции COVID-19, охватившая в 2020 году весь мир, изменила сложившиеся демографические тренды во многих странах, в том числе России. По данным Университета Джонса Хопкинса пандемия унесла жизни более 5 млн человек в мире. Новая эпидемиологическая ситуация оказалась стрессовой не только для экономик, служб здравоохранения, но в первую очередь для самих людей и неоднозначно отразилась на их самосохранительных практиках.

С конца марта 2020 года в российских регионах с целью ограничения распространения вируса был введен режим самоизоляции. Жителям разрешалось выходить из дома в строго оговоренном порядке, например, в ближайший продуктовый магазин или аптеку, чтобы выгулять домашнее животное или выбросить мусор, в ряде территорий для более свободного перемещения требовался специальный пропуск [1]. Большинству предприятий по возможности предлагалось перейти на дистанционный режим работы. Во всех регионах России до особого распоряжения были закрыты социальные объекты и ряд организаций за исключением социально значимых. С началом периода летних отпу- сков до осени произошло смягчение режима самоизоляции, но с появлением признаков «второй волны» пандемии меры по ужесточению норм и правил санитарно-эпидемической безопасности были вновь введены в регионах и по стране в целом [2, с. 10].

15 декабря 2020 года Министерство здравоохранения Российской Федерации объявило о начале вакцинации против COVID-19 во всех субъектах РФ. Первой официально зарегистрированной и прошедшей клинические испытания вакциной стала вакцина «Спутник V», разработанная НИЦЭМ им. Н.Ф. Гамалеи. В дальнейшем были одобрены и введены в эксплуатацию вакцины «Спутник Лайт», «ЭпиВакКорона» и «КовиВак» центра имени Чумакова. По состоянию на 13 октября 2021 года в России 49780040 человек (34\% всего населения) привито одним компонентом вакцины, 45219823 человека (31\% всего населения) привито полностью, в Вологодской области - привито хотя бы одним компонентом вакцины 324278 человек (28\% всего населения), привито полностью 307169 (26\% всего населения) 1 .

По состоянию на 2 ноября 2021 года общее число заболевших коронавирусной инфекцией в России составило 8455232 (в мире 247274026), число умерших - 236462 (в мире -

1 Сколько привито от коронавируса в России на 13 октября 2021 года // Гам Ковид Вак. Вакцина против коронавируса. URL: https://gam-kovid-vak.ru/skolko-privito-ot-koronavirusa-v-rossii-na-13-oktyabrya 
$5009007)^{2}$, в Вологодской области выявлено 79013 случаев заражения, зафиксировано 2211 случаев смерти ${ }^{3}$.

При этом нужно понимать, что статистика заболеваемости и смертности от нового вируса требует уточнения ввиду наличия ряда методических ограничений, связанных с периодом формирования рекомендаций и пересмотром международной классификации болезней [3].

Во время пандемии COVID-19 люди не перестали болеть другими болезнями, в т. ч. теми, что сочетанно или нет приводили к летальным исходам. Проблема мониторинга заболеваемости и летальности от заражения коронавирусом, как и в случае других эпидемий, актуальна: «Ученые и политики продолжают вести дискуссию о причинах появления коронавируса и статистике смертности. Сформировались в том числе среди врачей и специалистов сообщества COVIDдиссидентов и COVID-апологетов» [4, с. 35].

Медицинское сообщество оперативно изучало болезнь, были разработаны протоколы лечения, новые противовирусные препараты и вакцины [5; 6]. Так, уже в начале 2020 года выпущены методические рекомендации Министерства здравоохранения Российской Федерации «Профилактика, диагностика и лечение новой коронавирусной инфекции (COVID-19)». Один из самых острых вопросов - влияние вируса на течение беременности и здоровье ребенка, особенно с учетом выявленной возможности вертикального инфицирования от матери к ребенку [7-9].

Население в условиях противоречивости информации заняло выжидательную позицию, в том числе со стратегией избегания и откладывания вакцинации.А.Б.Спасенников резюмировал общее мнение о ситуации: «Государственная политика по разъяснению необходимости прохождения вакцинации уступает агитации «антипрививочников» [10, с. 116]. ВО3 включила недоверие к вак- цинации в список десяти глобальных угроз для здоровья населения. Неуверенность в вакцинации обусловлена отсутствием знаний, ложными религиозными убеждениями или дезинформацией о вакцинах [11]. Свою роль в распространении как официальной, так и фейковой информации играет сеть Интернет [12], что требует продолжения активной информационно-просветительской кампании. Несомненно, большое значение в формировании отношения населения к вакцинации имеют публикации в ведущих авторитетных медицинских изданиях и официальные методические рекомендации.

В 2021 году в стране были созданы условия для масштабной прививочной кампании, включая производственные мощности и четкие алгоритмы работы прививочных пунктов. Министерством здравоохранения разработаны стандартные операционные процедуры проведения вакцинации, определены логистические маршруты доставки вакцин в регионы страны. На базе НМИЦ терапии и профилактической медицины создан Федеральный дистанционный консультационный центр по вопросам вакцинации против новой коронавирусной инфекции COVID-19. В нем проводятся дистанционные семинары (каждая пятница; более 1500 подключений на каждом семинаре); информирование населения по телефонам горячей линии по вопросам вакцинации против новой коронавирусной инфекции COVID-19. С целью информационно-методического сопровождения медицинских сотрудников по вопросам вакцинации против COVID-19 создан telegram-канал «Все о вакцинации против COVID-19» [13, с. 8-9]. В научной среде доказана безопасность и эффективность вакцинации при борьбе с коронавирусной инфекцией, в т. ч. для беременных женщин [14].

Важнейшим фактором народосбережения в данных условиях выступает самосохранительное поведение. От того, насколько

2 WHO Coronavirus (COVID-19) Dashboard. World Health Organization. URL: https://covid19.who.int; COVID-19 Dashboard by the Center for Systems Science and Engineering (CSSE) at Johns Hopkins University (JHU). URL: https://www.arcgis.com/apps/dashboards/bda7594740fd40299423467b48e9ecf6

3 Оперативные данные по коронавирусной инфекции // Стопкоронавирус.pф. URL: https://xn--80aesfpebagmfblc0a. xn--p1ai/information 
соблюдаются противоэпидемические меры, насколько ответственно подходят люди к профилактике заболевания, зависят скорость и масштабы его распространения. На этапе изучения нового вируса и разработки эффективных мер борьбы с ним время является ключевым фактором снижения демографических потерь, обусловленных избыточной смертностью.

В работе, подводя демографические итоги 2020 года, мы ставили задачу оценить возможные проблемы статистического учета и вклада пандемии COVID-19 в смертность и заболеваемость населения, а также тренды самосохранительного поведения в условиях ограничительных мер распространения инфекции.

\section{Информационная база \\ и методы исследования}

Информационную базу исследования составили данные Федеральной службы государственной статистики, Министерства здравоохранения и результаты опросов населения. Для анализа демографической ситуации изучена динамика таких показателей, как численность населения и компоненты ее изменения, заболеваемость населения, смертность населения по причинам смерти, возрастам и гендерному признаку (структура смертности), ожидаемая продолжительность жизни. Статистические данные анализировались с применением таблично-графических методов, группировки и типологизации (в части выявления территориальных различий движения населения). Для выявления особенностей самосохранительного поведения населения в условиях пандемии применены методы социологических исследований, в частности массовые анкетные опросы населения Вологодской области в рамках мониторинга физического здоровья и изучения общественного мнения. Мониторинг физического здоровья осуществляется по авторской методике Вологодского научного центра РАН с 1999 года [15, с. 58-61], в 2012 году разработана методика исследования самосохра- нительного поведения [16], позволяющая оценить самосохранительные мотивы, установки, практики, попытки изменения образа жизни и их успешность, факторы формирования модели самосохранительного поведения. Мониторинг общественного мнения в вариативном блоке инструментария содержал блок вопросов о соблюдении мер, рекомендованных для сдерживания распространения коронавирусной инфекции, отношении к вакцинации. Объем выборки 1500 человек. Выборка квотная по полу и возрасту, территории проживания. Также использовались вторичные данные опросов по сходной проблематике, проведенных в других регионах страны.

\section{Результаты исследования}

\section{Демографический баланс 2020 года}

На 1 января 2021 года численность населения России составила 146171015 человек. Это на 577,6 тыс. человек меньше, чем по данным на 1 января 2020 года. В «допандемийном» 2019 году общая убыль населения составила 32,1 тыс. человек (рис. 1).

С 2000 по 2020 год общий коэффициент рождаемости вырос в среднем по России на $13 \%$ (с 8,7 до 9,8 случая на 1000 чел. населения; табл. 1). За этот же период общий коэффициент смертности сократился на 5\% (с 15,3 до 14,6 случая на 1000 чел. населения). В результате тенденций в динамике показателей рождаемости и смертности наблюдалось снижение коэффициента естественной убыли населения (с -6,6 до -4,8 на 1000 чел. населения).

Однако в 2020 году по сравнению с предшествующим 2019 годом в России сократился уровень рождаемости (на 3\% соответственно) при одновременном увеличении уровня смертности на $19 \%$, что обусловило значительный рост коэффициента естественной убыли.

С начала столетия в стране наблюдался миграционный приток населения, который компенсировал естественную убыль только в период с 2009 по 2017 год. В 2020 году миграционный прирост компенсировал $22 \%$ естественной убыли. 


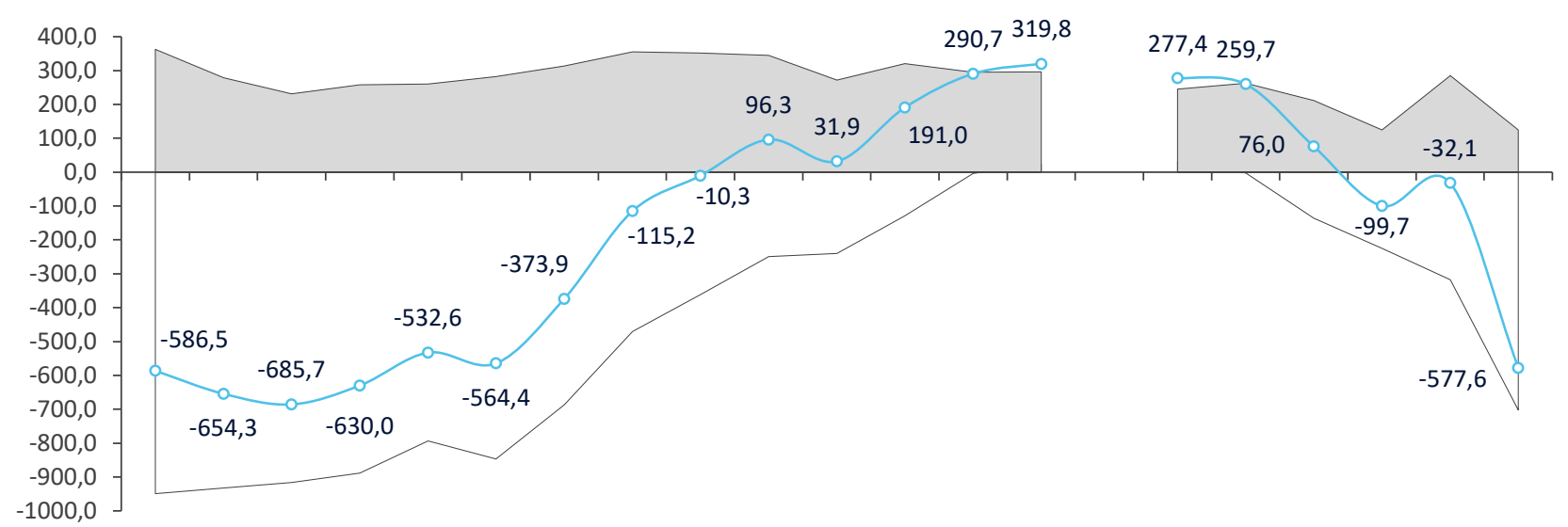

200020012002200320042005200620072008200920102011201220132014201520162017201820192020

$\square$ Естественный прирост/убыль

$\square$ Миграционный прирост/убыль

— Общий прирост/убыль

Рис. 1. Компоненты изменения численности населения России в 2000-2020 гг., тыс. человек

Примечание: Данные по численности населения на 1 января 2004-2010 гг. и миграционный прирост за 2004-2010 гг. пересчитаны с учетом итогов ВПН-2010; общий прирост в \% за 2003-2010 гг. рассчитан с использованием численности населения, пересчитанной с учетом итогов ВПН-2010. Общий прирост численности населения в \% за 2014 год рассчитан без учета численности населения по Республике Крым и г. Севастополю. Данные за 2015 и последующие годы приведены с учетом численности населения Республики Крым и г. Севастополя.

Источник: Демография. Компоненты изменения численности населения Российской Федерации // Фед. служба гос. статистики. URL: https://www.gks.ru/folder/12781

Таблица 1. Показатели естественного движения населения России, на 1000 чел. населения, промилле

\begin{tabular}{|c|c|c|c|c|c|c|c|c|}
\hline \multirow{2}{*}{ Показатель * } & \multicolumn{6}{|c|}{ Год } & \multicolumn{2}{|c|}{2020 год к..., \% } \\
\hline & 2000 & 2005 & 2010 & 2015 & 2019 & 2020 & 2000 году & 2019 году \\
\hline OKP & 8,7 & 10,2 & 12,5 & 13,3 & 10,1 & 9,8 & 112,6 & 97,0 \\
\hline OKC & 15,3 & 16,1 & 14,2 & 13,0 & 12,3 & 14,6 & 95,4 & 118,7 \\
\hline КЕП/У & $-6,6$ & $-5,9$ & $-1,7$ & 0,3 & $-2,2$ & $-4,8$ & - & - \\
\hline \multicolumn{9}{|c|}{$\begin{array}{l}\text { * ОКР - общий коэффициент рождаемости, ОКС - общий коэффициент смертности, КЕП/У - коэффициент естествен- } \\
\text { ного прироста/убыли. } \\
\text { Источник: Единая межведомственная информационно-статистическая система // Фед. служба гос. статистики. } \\
\text { URL: https://fedstat.ru }\end{array}$} \\
\hline
\end{tabular}

В 2020 году в региональном разрезе число субъектов с самой неблагоприятной демографической ситуацией (естественной, миграционной и общей убылью населения) составило больше половины - 45 , в то время как количество регионов с самой благоприятной ситуацией (естественным, миграционным и общим приростом населения) - лишь 5. Депопуляция зафиксирована в 66 субъектах Российской Федерации.

Структура смертности населения. Вклад COVID-19

Структура смертности населения по причине смерти в 2020 году в целом традиционная для последнего двадцатилетия.
Лидирующую позицию сохраняют болезни сердечно-сосудистой системы, второе и третье места занимают новообразования и внешние причины (табл. 2). Вклад коронавирусной инфекции в общую смертность населения в 2020 году составил 7\%, что больше доли инфекционных и паразитарных заболеваний $(1,4 \%)$, болезней органов дыхания $(4,5 \%)$ и пищеварения (5\%), внешних причин (6,5\%).

Вклад мужчин и женщин в общую смертность населения страны в 2020 году в целом оказался сопоставимым (51 и 49\% соответственно), однако существенные гендерные различия обнаруживаются внутри отдельных 
Таблица 2. Структура смертности населения России от основных классов причин смерти в 2000-2020 гг., на 100 тыс. чел. населения, \% от общего числа умерших

\begin{tabular}{|c|c|c|c|c|c|c|c|c|c|c|c|c|c|c|}
\hline \multirow{2}{*}{$\begin{array}{c}\text { Класс } \\
\text { причин }\end{array}$} & \multicolumn{2}{|c|}{2000 год } & \multicolumn{2}{|c|}{2005 год } & \multicolumn{2}{|c|}{2010 год } & \multicolumn{2}{|c|}{2015 год } & \multicolumn{2}{|c|}{2019 год } & \multicolumn{2}{|c|}{2020 год } & \multicolumn{2}{|c|}{2020 год к ..., \% } \\
\hline & КОэф-Т & $\%$ & кОэф-т & $\%$ & КОэф-т & $\%$ & КОэф-т & $\%$ & коэф-т & $\%$ & КОэф-т & $\%$ & $\begin{array}{l}2000 \\
\text { году }\end{array}$ & $\begin{array}{l}2019 \\
\text { году }\end{array}$ \\
\hline Все причины & 1529,0 & 100,0 & 1605,3 & 100,0 & 1420,0 & 100,0 & 1303,6 & 100,0 & 1225,3 & 100,0 & 1460,2 & 100,0 & 95,5 & 119,2 \\
\hline БСК & 846,1 & 55,3 & 905,4 & 56,4 & 806,4 & 56,8 & 635,3 & 48,7 & 573,2 & 46,8 & 640,8 & 43,9 & 75,7 & 111,8 \\
\hline HO & 204,7 & 13,4 & 200,6 & 12,5 & 205,2 & 14,5 & 205,1 & 15,7 & 203,5 & 16,6 & 202,0 & 13,8 & 98,7 & 99,3 \\
\hline ВП & 219,0 & 14,3 & 220,1 & 13,7 & 151,7 & 10,7 & 121,3 & 9,3 & 93,8 & 7,7 & 95,3 & 6,5 & 43,5 & 101,6 \\
\hline БОП & 44,4 & 2,9 & 65,4 & 4,1 & 64,4 & 4,5 & 69,6 & 5,3 & 67,0 & 5,5 & 73,3 & 5,0 & 165,1 & 109,4 \\
\hline БОД & 70,2 & 4,6 & 66,0 & 4,1 & 52,4 & 3,7 & 51,8 & 4,0 & 40,3 & 3,3 & 65,9 & 4,5 & 93,9 & 163,5 \\
\hline ИПЗ & 24,9 & 1,6 & 27,2 & 1,7 & 23,5 & 1,7 & 23,5 & 1,8 & 22,4 & 1,8 & 20,6 & 1,4 & 82,7 & 92,0 \\
\hline COVID-19* & - & - & - & - & - & - & - & - & - & - & 98,8 & 6,8 & - & - \\
\hline
\end{tabular}

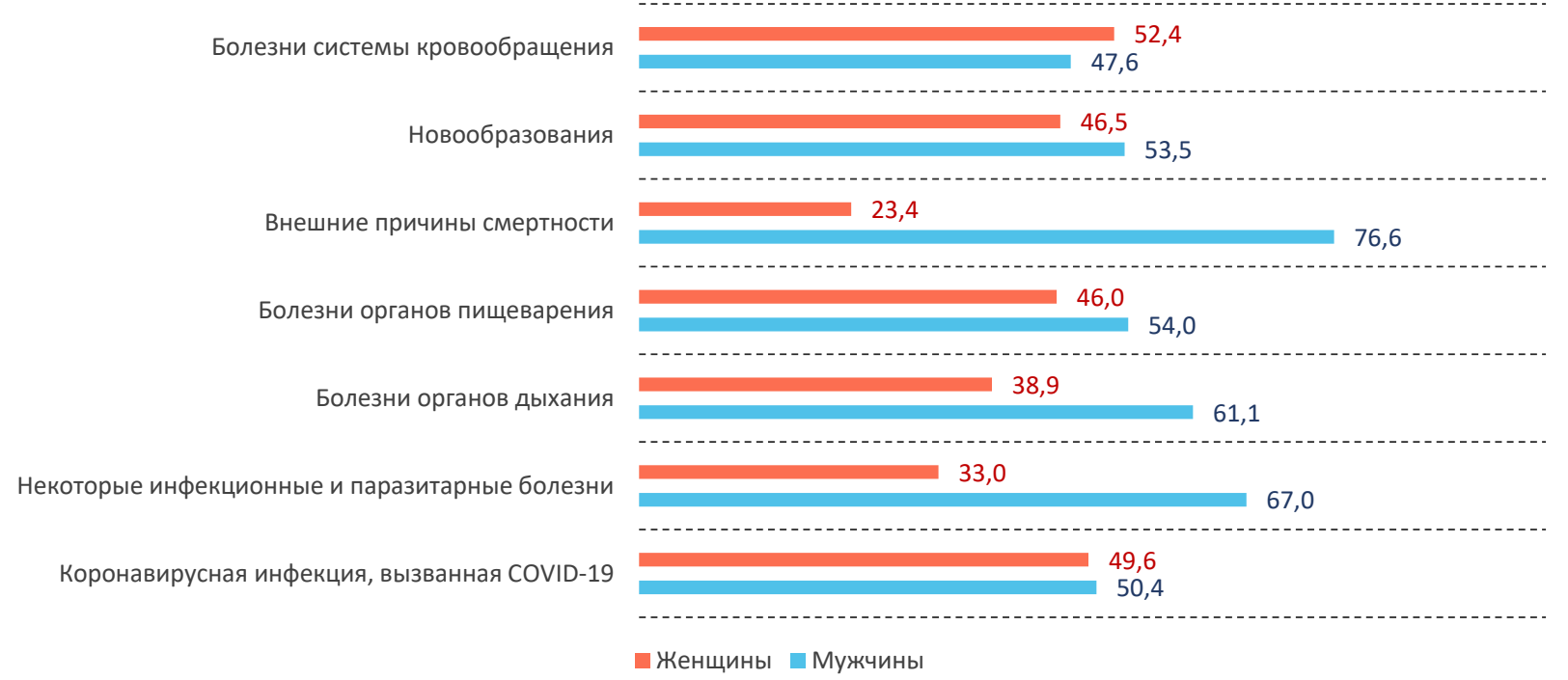

Рис. 2. Вклад мужского и женского населения России в общую смертность от основных классов причин смерти, 2020 год, \%

Рассчитано по: данные Росстата.

классов причин смерти. Доля мужских смертей превышает женские в рамках таких нозологий, как внешние причины (77 против 23\%), болезни органов дыхания (61 против 39\%), некоторые инфекционные и паразитарные болезни (67 против 33\%), новообразования (54 против 46\%) и болезни органов пищеварения (54 против 46\%; рис. 2). Вклад мужчин в смертность от коронавирусной инфекции, вызванной COVID-19, равноценен женскому.

Анализ возрастного профиля смертности закономерно подтвердил тот факт, что основ- ная масса смертей приходится на возрастную группу 60 лет и старше (78\%; puc. 3). Тем не менее в 2020 году почти каждый четвертый умерший не доживал до возраста 60 лет (22\%), а 8\% - до возраста 45 лет. Однако вклад возрастных групп в общую смертность заметно варьируется в зависимости от нозологической группы причин. Среди умерших от инфекционных и паразитарных заболеваний 59\% составляют люди в возрасте до 45 лет, из них 54\% представители возрастной группы 30-44 года. Также велика доля не доживших до 45 лет вну- 


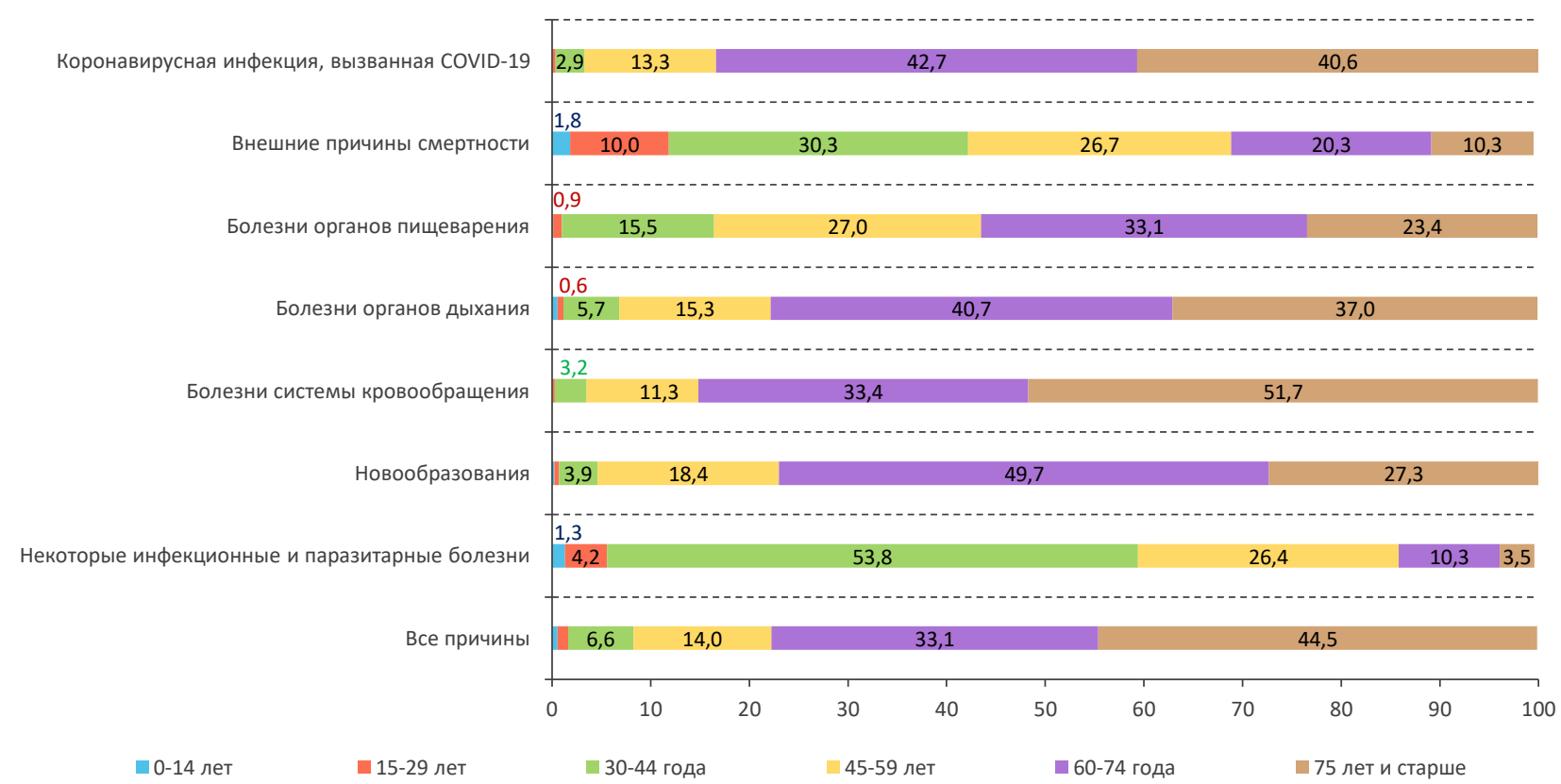

Рис. 3. Вклад возрастных групп в смертность населения России от основных классов и групп причин смерти, 2020 год, \%

Рассчитано по: данные Росстата.

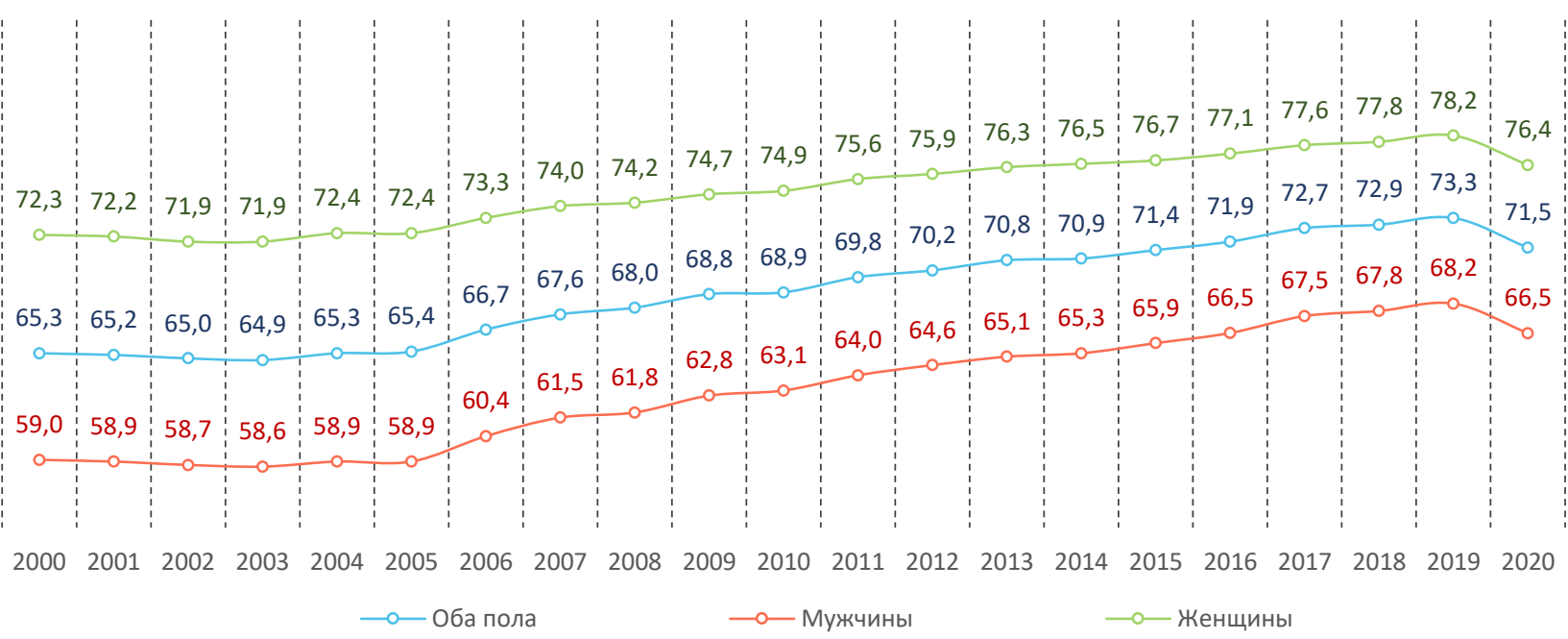

Рис. 4. Динамика ожидаемой продолжительности жизни населения России в 2000-2020 гг., лет Источник: Единая межведомственная информационно-статистическая система // Фед. служба гос. статистики. URL: https://fedstat.ru

три класса «внешние причины смерти» $-42 \%$, из которых 30\% также приходится на возраст 30-44 года, $12 \%$ - на детей и молодежь до 30 лет. До 60 лет не дожили 86\% умерших от инфекционных и паразитарных заболеваний и 69\% умерших от внешних причин, что отражает существенный вклад данных классов причин в преждевременную смертность населения. На старшие возрастные группы (60 лет и старше) приходится большинство смертей от болезней системы кровообращения (85\%), новообразований (77\%), а также новой коронавирусной инфекции (83\%).

Рост смертности привел к снижению ожидаемой продолжительности жизни. Сокращение ОПЖ в 2020 году по сравнению с 2019 годом оказалось существенным: в целом по России на 1,8 года (с 73,3 до 71,5 года). При этом ОПЖ мужчин снизилась на 1,7 года, женщин - на 1,8 года (рис. 4). 


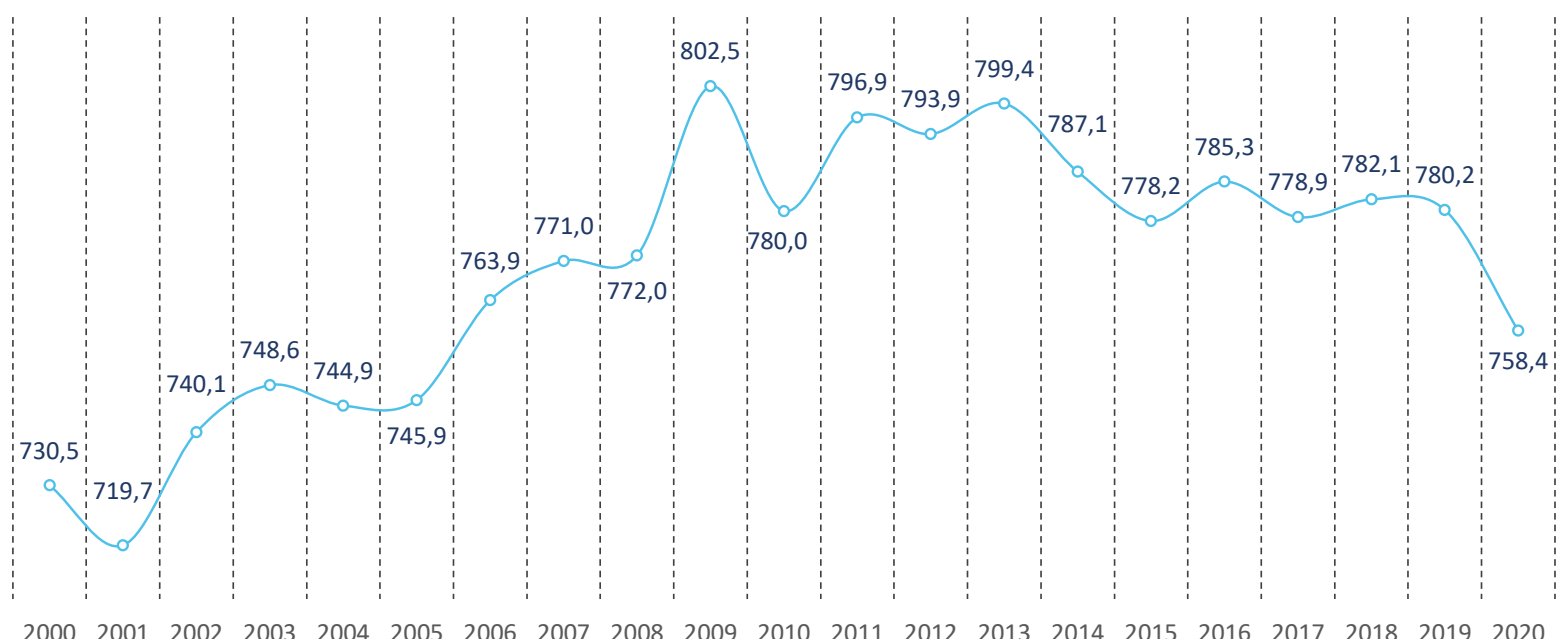

Рис. 5. Первичная заболеваемость населения России в 2000-2020 гг., впервые выявленных случаев на 1000 чел. населения

Источники: Регионы России. Социально-экономические показатели: стат. сб. // Фед. служба гос. статистики. URL: https://rosstat.gov.ru/bgd/regl/b1914p/Main.htm; Здравоохранение Российской Федерации. Итоги 2020: доклад об итогах работы Министерства здравоохранения РФ в 2020 году и задачах на 2021 год. М.: Минздрав РФ. 180 с.

Заболеваемость населения. Верить ли цифрам?

Коэффициент первичной заболеваемости населения отражает число впервые выявленных случаев болезни в расчете на 1000 чел. населения. При его анализе важно понимать, что, с одной стороны, он характеризует состояние общественного здоровья (уровень заболеваемости), с другой - выявляемость болезней в учреждениях здравоохранения, которая зависит как от качества и доступности медицинской помощи, так и от уровня обращаемости в них населения [17, с. 28]. В 2020 году по сравнению с 2019 годом первичная заболеваемость населения сократилась на 3\%, с 780,2 до 758,4 случая на 1000 человек (рис. 5).

Снижение первичной заболеваемости может быть связано с периодами локдауна и самоизоляции, повлиявшими на медицинскую активность населения, и переориентацией деятельности учреждений здравоохранения на оказание медицинской помощи заболевшим коронавирусной инфекцией в условиях пандемии.

В целом по России заболеваемость коронавирусной инфекцией в 2020 году составила 22 случая на 1000 человек (2153 на 100000 человек) [18].
Самосохранительные практики в пандемию. Рецепт от стресса

Пандемия коронавирусной инфекции и введенные карантинные меры неизбежно оказали влияние на жизнь россиян. Новые риски для здоровья, обусловленные эпидемией, диктуют необходимость более ответственного отношения к нему у каждого человека и принятия соответствующих мер в отношении его сохранения и укрепления.

Парадоксально или объяснимо, но в 2020 году, согласно социологическому мониторингу физического здоровья населения Вологодской области ${ }^{4}$, по сравнению с допандемическим периодом население стало реже соблюдать умеренность в потреблении алкоголя (на 7 п. п., рис. 6), поддерживать здоровый режим и рацион питания (на 4 п. п.), проходить санаторно-курортное лечение (на 4 п. п.), стараться оптимально сочетать трудовые нагрузки и отдых (на 4 п. п.). Снижение удельного веса тех, кто в целях укрепления здоровья проходит санаторнокурортное лечение, вполне объяснимо ввиду введения в 2020 году ряда ограничительных мер - самоизоляции, запрета на перемещение людей и их массовые скопления, как следствие, приостановления работы санаторно-курортных учреждений. Воз-

4 В 2020 году анкетирование проводилось в период пандемии коронавирусной инфекции и действия ограничительных карантинных мер (июнь - июль 2020 года). 


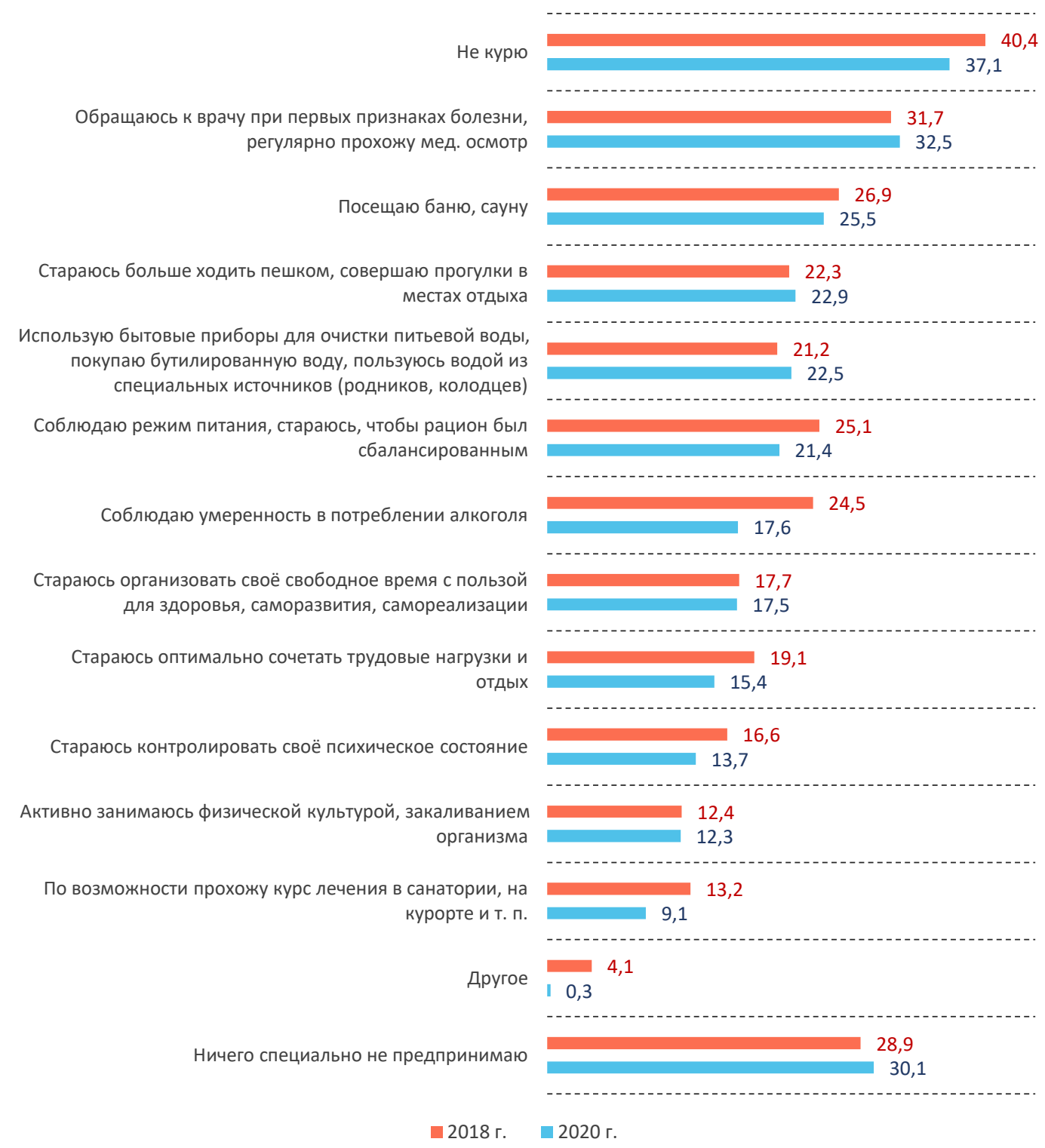

Рис. 6. Распределение ответов респондентов на вопрос «Что Вы лично предпринимаете для сохранения и укрепления своего здоровья?»*, \% от числа ответивших

* Вопрос предполагал выбор нескольких вариантов ответа, поэтому сумма их в столбце не равна $100 \%$. Источник: мониторинг физического здоровья населения Вологодской области, 2018 и 2020 гг. (N = 1500).

растание показателей потребления алкоголя, ухудшение настроения и психического состояния населения признаются одними из ожидаемых результатов пандемии и введения жестких карантинных мер [19, с. 91]. Все это могло стать причиной отказа от следования остальным практикам здорового образа жизни. Доля респондентов, ничего не предпринимавших в целях здоровьесбережения, по данным опроса 2020 года, составила 30\% (29\% в 2018 году), что может говорить о довольно широком распространении попустительского отношения к собственному здо- ровью среди жителей региона, даже несмотря на сложную эпидемиологическую обстановку в стране и мире [20].

Согласно данным опроса 2020 года жители региона чаще всего проводили следующие оздоровительные практики: пытались меньше волноваться и испытывать стресс (33\%), сократить потребление сахара (31\%) и соли (26\%), увеличить физическую активность (27\%), соблюдать баланс труда и отдыха (26\%), а среди курильщиков - бросить курить (25\%). Реже всего респонденты прибегали к ограничению количества потребля- 


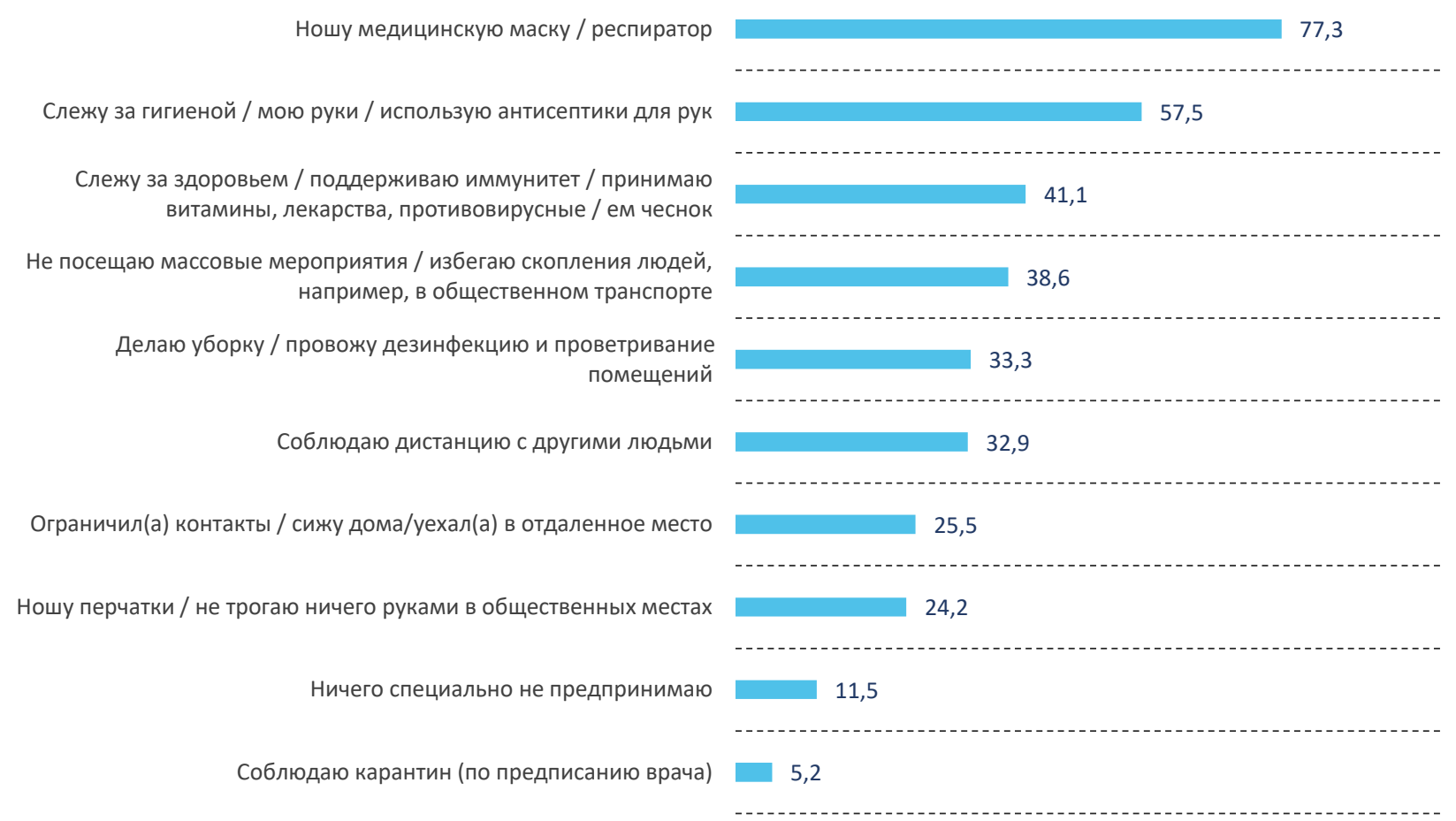

Рис. 7. Распределение ответов респондентов на вопрос «Скажите, пожалуйста, какие меры Вы уже предпринимаете, чтобы обезопасить себя и свою семью от коронавируса?»*, \% от числа опрошенных

* Респондентам предлагалось выбрать любое количество вариантов ответа. Источник: опрос общественного мнения об изменении условий жизни населения Вологодской области, декабрь 2020 года $(\mathrm{N}=1500)$.

емого алкоголя (13\%), что тесно соотносится с ранее выявленной тенденцией сокращения доли населения, реализующего данную практику в целях сохранения и укрепления здоровья.

Интересным представляется поведение населения Вологодской области в отношении профилактики заражения новой коронавирусной инфекцией. Анкета мониторинга общественного мнения об изменении условий жизни населения региона, проведенного ФГБУН ВолНЦ РАН в декабре 2020 года ${ }^{5}$, содержала соответствующий вопрос. Согласно полученным данным самой распространенной мерой профилактики коронавируса в практиках жителей региона стало ношение медицинской маски или респиратора (77\%; puc. 7). Также довольно популярными методами защиты от инфекции оказались соблюдение гигиены рук - мытье, использование антисептиков (58\%), поддержка иммунитета - прием витаминов, противовирусных препаратов и пр. (41\%), отказ от посещения массовых мероприятий и нахождения в местах скопления людей (39\%), уборка, проветривание и дезинфекция помещений (33\%), соблюдение социальной дистанции (33\%). Наименее распространенной мерой стало соблюдение карантина (5\%). Ничего не предпринимали для профилактики коронавирусной инфекции 12\% опрошенных жителей области.

5 Результаты опроса общественного мнения об изменении условий жизни населения Вологодской области, проведенного ФГБУН ВолНЦ РАН в декабре 2020 года. Объем выборки - 1500 респондентов старше 18 лет, проживающих в городах Вологде и Череповце, а также в Бабаевском, Великоустюгском, Вожегодском, Грязовецком, Кирилловском, Никольском, Тарногском, Шекснинском районах. Репрезентативность выборки обеспечивается соблюдением пропорций между городским и сельским населением; между жителями населенных пунктов различных типов (сельские населенные пункты, малые и средние города); половозрастной структуры взрослого населения области. Метод опроса - анкетирование по месту жительства респондентов. Ошибка выборки не превышает $3 \%$. 
Обнаруживаются социально-демографические различия в отношении предпринимаемых мер профилактики COVID-19. Так, среди использующих какие-либо меры предупреждения коронавирусной инфекции значительно чаще по сравнению с теми, кто не соблюдает никаких мер, встречались женщины (62\%), люди с высшим и послевузовским образованием (35\%), наиболее обеспеченные (23\%), а также жители областного центра - г. Вологды (33\%; табл. 3). В свою очередь отказ от мер профилактики в большей степени характерен для мужчин (52\%), респондентов со средним и ниже среднего образованием (37\%), а также жителей муниципальных районов области (51\%).

\section{Таблица 3. Социально-демографические характеристики респондентов, соблюдающих и не соблюдающих меры профилактики коронавирусной инфекции, $\%$ от числа опрошенных}

\begin{tabular}{|c|c|c|}
\hline $\begin{array}{c}\text { Социально- } \\
\text { демографические } \\
\text { характеристики } \\
\end{array}$ & $\begin{array}{c}\text { Слежу за гигиеной / мою руки / } \\
\text { использую антисептики для рук; } \\
\text { ношу маску / респиратор }\end{array}$ & Остальные \\
\hline \multicolumn{3}{|c|}{ Пол } \\
\hline Мужской & 38,0 & 51,9 \\
\hline Женский & 62,0 & 48,1 \\
\hline \multicolumn{3}{|c|}{ Возраст } \\
\hline До 30 лет & 14,3 & 16,4 \\
\hline 30-55 лет & 46,8 & 45,8 \\
\hline Старше 55 лет & 38,9 & 37,7 \\
\hline \multicolumn{3}{|c|}{ Образование } \\
\hline $\begin{array}{l}\text { Среднее } \\
\text { и н/среднее }\end{array}$ & 29,0 & 37,1 \\
\hline $\begin{array}{l}\text { Среднее } \\
\text { специальное }\end{array}$ & 36,3 & 40,0 \\
\hline $\begin{array}{l}\text { Высшее } \\
\text { и н/высшее }\end{array}$ & 34,7 & 22,9 \\
\hline \multicolumn{3}{|c|}{ Доходные группы } \\
\hline $\begin{array}{l}20 \% \text { наименее } \\
\text { обеспеченных }\end{array}$ & 19,7 & 20,3 \\
\hline $\begin{array}{l}\text { 60\% средне- } \\
\text { обеспеченных }\end{array}$ & 57,2 & 63,0 \\
\hline $\begin{array}{l}20 \% \text { наиболее } \\
\text { обеспеченных }\end{array}$ & 23,1 & 16,7 \\
\hline \multicolumn{3}{|c|}{ Территория } \\
\hline Вологда & 33,0 & 19,4 \\
\hline Череповец & 24,4 & 29,8 \\
\hline Районы & 42,6 & 50,8 \\
\hline
\end{tabular}

\section{Отношение населения к вакциинации от COVID-19}

По данным социологического мониторинга ВЦИОМ, посвященного отношению россиян к вакцинации от коронавирусной инфекции ${ }^{6}$, на 6 июня 2021 года доля россиян, положительно относящихся к массовой вакцинации населения страны, составила 60\%, что на 5 п. п. больше, чем по данным опроса от 21 января 2021 года, тогда как доля отрицательных оценок достигла $22 \%$, что на 8 п. п. меньше, чем в начале года (табл. 4). Вместе с тем несколько вырос удельный вес респондентов, безразлично относящихся к вакцинации (с 9 до 15\%). В целом наблюдаемые в общественном мнении тенденции свидетельствуют об улучшении отношения россиян к массовой вакцинации от COVID-19.

Согласно данным ВЦИОМ, в декабре 2020 года никто из опрошенных респондентов не проходил вакцинацию от коронавирусной инфекции, доля собиравшихся сделать прививку составляла 38\%, а тех, кто не планировал введение вакцины, - 52\% (табл. 5). K июню 2021 года доля вакцинированных среди опрошенных россиян уже достигла $17 \%$, а тех, кто планирует вакцинироваться, - 38\%, удельный вес противников введения прививки составил 42\%, что на 10 п. п. меньше, чем в декабре 2020 года. Таким образом, отмечается тенденция роста как готовности населения к вакцинации от коронавирусной инфекции, так и доли тех, кто уже прошел вакцинацию.

Главным мотивом для тех, кто выразил готовность вакцинироваться, выступает страх болезни и заражения других людей (13\%), тогда как среди причин отказа от вакцинации лидирует мнение о том, что вакцина недостаточно исследована,

6 Вакцинация от коронавируса: мониторинг // ВЦИОМ. URL: https://wciom.ru/analytical-reviews/ analiticheskii-obzor/vakcinacija-ot-koronavirusamonitoring-1

7 Вакцинация: ключ на старт! // ВЦИOM. URL: https://wciom.ru/analytical-reviews/analiticheskii-obzor/ vakcinacija-kljuch-na-start; Вакцинация от коронавируса: мониторинг // ВЦИОМ. URL: https://wciom. $\mathrm{ru}$ /analytical-reviews/analiticheskii-obzor/vakcinacijaot-koronavirusa-monitoring-1 
Таблица 4. Распределение ответов респондентов на вопрос «Скажите, пожалуйста, как Вы относитесь к массовой вакцинации россиян от коронавируса?»*, \% от числа опрошенных

\begin{tabular}{|l|c|c|c|c|c|c|}
\hline \multicolumn{1}{|c|}{ Вариант ответа } & $\begin{array}{c}21 \text { января } \\
2021 \text { года }\end{array}$ & $\begin{array}{c}28 \text { февраля } \\
2021 \text { года }\end{array}$ & $\begin{array}{c}28 \text { марта } \\
2021 \text { года }\end{array}$ & $\begin{array}{c}26 \text { апреля } \\
2021 \text { года }\end{array}$ & $\begin{array}{c}6 \text { июня } \\
2021 \text { года }\end{array}$ & Изменение, п. п. \\
\hline Определенно положительно & 26 & 29 & 31 & 30 & 31 & +5 \\
\hline Скорее положительно & 29 & 32 & 30 & 35 & 29 & 0 \\
\hline Скорее отрицательно & 16 & 12 & 11 & 9 & 10 & -6 \\
\hline Определенно отрицательно & 14 & 11 & 11 & 8 & 12 & -2 \\
\hline Безразлично & 9 & 12 & 12 & 13 & 15 & +6 \\
\hline Затрудняюсь ответить & 6 & 4 & 4 & 5 & 3 & -3 \\
\hline $\begin{array}{l}\text { * Закрытый вопрос, предполагающий один вариант ответа. } \\
\text { Источник: Вакцинация от коронавируса: мониторинг // ВцИОМ. URL: https://wciom.ru/analytical-reviews/analiticheskii- } \\
\text { оbzor/vakсіпасіја-от-kоronаvirusa-топіtoring-1 }\end{array}$ \\
\hline
\end{tabular}

Таблица 5. Распределение ответов респондентов на вопрос «Стали бы Вы себе делать прививку российской вакциной от коронавируса или нет?»*, \% от числа опрошенных

\begin{tabular}{|c|c|c|c|c|}
\hline Вариант ответа & $\begin{array}{c}\text { Декабрь } \\
2020 \text { года }\end{array}$ & $\begin{array}{l}26 \text { апреля } \\
2021 \text { года }\end{array}$ & $\begin{array}{c}6 \text { июня } \\
2021 \text { года }\end{array}$ & Изменение, п. п. \\
\hline Точно сделаю & 13 & 21 & 16 & +3 \\
\hline Скорее сделаю & 25 & 25 & 22 & -3 \\
\hline Скорее не стану делать & 20 & 19 & 16 & -4 \\
\hline Точно не стану делать & 32 & 20 & 26 & -6 \\
\hline Уже сделал(а) прививку от коронавируса & 0 & 11 & 17 & +17 \\
\hline Затрудняюсь ответить / еще не решил(а) & 10 & 4 & 3 & -7 \\
\hline \multicolumn{5}{|c|}{$\begin{array}{l}\text { * Закрытый вопрос, предполагающий один вариант ответа. } \\
\text { Источники: Вакцинация: ключ на старт! // ВЦИОМ. URL: https://wciom.ru/analytical-reviews/analiticheskii-obzor/ } \\
\text { vakcinacija-kljuch-na-start; Вакцинация от коронавируса: мониторинг // ВЦИOM. URL: https://wciom.ru/analytical- } \\
\text { reviews/analiticheskii-obzor/vakcinacija-ot-koronavirusa-monitoring-1 }\end{array}$} \\
\hline
\end{tabular}

а также страх перед последствиями (по 8\% соответственно $)^{8}$.

Жители Вологодской области в октябре 2020 года в отношении вакцинации от коронавируса были настроены довольно скептически: только 15\% опрошенных ответили, что хотели бы сделать прививку и еще $10 \%$ при наличии «вынуждающих» обстоятельств (табл. 6). Среди населения районов области по сравнению с жителями крупных городов было больше ориентированных на вакцинацию (при том, что «антипрививочников» примерно равные доли - около трети как среди горожан, так и среди жителей муниципальных районов).
В феврале 2021 г. 25\% вологжан собирались сделать прививку (жители административного и промышленного центров региона по-прежнему были настроены более осторожно), 3\% на тот момент уже вакцинировались (табл. 7). Более трети жителей региона сомневались, какое решение им следует принять.

Ключевые причины наличия антипрививочных настроений связаны с опасениями по поводу качества и эффективности вакцины (табл. 8). Очевидно, что население испытывало дефицит информации: о вакцинации и российской вакцине были осведомлены «хорошо» (по самооценке) 46\% опрошенных.

8 Вакцинация от коронавируса: мониторинг // ВЦИОМ. URL: https://wciom.ru/analytical-reviews/analiticheskiiobzor/vakcinacija-ot-koronavirusa-monitoring-1 
А.А. Шабунова, О.Н. Калачикова, А.В. Короленко | Демографические итоги 2020 года...

Таблица 6. Распределение ответов жителей Вологодской области на вопрос «В России зарегистрирована вакцина от коронавируса, которая находится на стадии апробации. Вы бы хотели сделать прививку?», \% от числа опрошенных

\begin{tabular}{|c|c|c|c|c|}
\hline Ответ & Вологда & Череповец & Районы & Область \\
\hline Да, так как прививка поможет защититься от коронавируса & 4,4 & 2,7 & 13,9 & 8,3 \\
\hline Да, предпочту поставить прививку на всякий случай & 6,4 & 4,9 & 8,7 & 7,0 \\
\hline $\begin{array}{l}\text { Да, но только если по месту моей работы/учебы будут наста- } \\
\text { ивать на этом }\end{array}$ & 5,9 & 8,8 & 4,7 & 6,1 \\
\hline $\begin{array}{l}\text { Да, если это будет нужно, чтобы поехать куда-то отдыхать } \\
\text { или в командировку }\end{array}$ & 3,9 & 5,6 & 3,4 & 4,1 \\
\hline $\begin{array}{l}\text { Нет, так как прививка не поможет защититься от корона- } \\
\text { вируса }\end{array}$ & 7,8 & 5,1 & 8,7 & 7,5 \\
\hline Нет, так как прививка может навредить моему здоровью & 22,1 & 22,4 & 7,8 & 15,7 \\
\hline Я против любых прививок & 28,4 & 30,0 & 27,7 & 28,5 \\
\hline Затрудняюсь ответить & 21,1 & 20,5 & 25,2 & 22,8 \\
\hline
\end{tabular}

Таблица 7. Распределение ответов жителей Вологодской области на вопрос «Скажите, пожалуйста, Вы собираетесь или не собираетесь делать прививку вакциной от коронавируса?», \% от числа опрошенных

\begin{tabular}{|l|c|c|c|c|}
\hline \multicolumn{1}{|c|}{ Ответ } & Вологда & Череповец & Районы & Область \\
\hline Точно сделаю & 3,8 & 5,4 & 15,4 & 9,7 \\
\hline Скорее сделаю & 11,9 & 11,1 & 20,4 & 15,7 \\
\hline Скорее не стану делать & 18,9 & 17,6 & 11,6 & 15,1 \\
\hline Точно не стану делать & 25,0 & 15,8 & 19,7 & 20,1 \\
\hline Точно и скорее сделаю & 15,7 & 16,6 & 35,9 & 25,3 \\
\hline Точно и скорее не стану делать & 43,9 & 33,4 & 31,3 & 35,2 \\
\hline Уже сделал(а) прививку от коронавируса & 2,5 & 1,0 & 3,9 & 2,7 \\
\hline Затрудняюсь ответить & 18,2 & 17,6 & 9,9 & 14,1 \\
\hline Еще не решил(а) & 19,7 & 31,4 & 19,1 & 22,6 \\
\hline Источник: & & & 2 \\
\hline
\end{tabular}

Источник: опрос общественного мнения об изменении условий жизни населения Вологодской области, февраль 2021 года $(\mathrm{N}=1500)$.

Таблица 8. Распределение ответов жителей Вологодской области на вопрос «Если Вы не собираетесь делать прививку вакциной, то почему?», \% от числа опрошенных

\begin{tabular}{|l|c|c|c|c|}
\hline \multicolumn{1}{|c|}{ Ответ } & Вологда & Череповец & Районы & Область \\
\hline Надо дождаться окончания всех испытаний & 24,1 & 22,2 & 24,2 & 23,7 \\
\hline Опасаюсь побочных действий этой вакцины & 42,5 & 42,2 & 28,3 & 36,6 \\
\hline Имею противопоказания & 17,2 & 21,5 & 14,6 & 17,2 \\
\hline Нет смысла делать прививку от коронавируса & 24,1 & 15,6 & 38,8 & 28,0 \\
\hline В целом против любых прививок & 16,1 & 12,6 & 27,4 & 19,9 \\
\hline Другое & 1,7 & 0,0 & 0,5 & 0,8 \\
\hline Затрудняюсь ответить & 11,5 & 2,2 & 0,9 & 4,7 \\
\hline
\end{tabular}

Источник: опрос общественного мнения об изменении условий жизни населения Вологодской области, февраль 2021 года $(\mathrm{N}=1500)$. 


\section{Заключение}

2020 и 2021 гг. войдут в демографическую историю России и мира особой страницей, изменив сложившиеся к этому времени тренды. Пандемия существенно увеличила «вычитаемое» демографического баланса. В России смертность населения выросла на 19\%, естественная убыль уже не компенсируется миграционным приростом. Вклад коронавируса в структуру общей смертности составил 7\%, что выше доли смертей от внешних причин (по оценке как 2020, так и 2019 года, когда коронавирус в структуре причин смертности не выделялся). Заболеваемость коронавирусом составила 22 случая на 1000 человек. Статистическим артефактом является фиксируемое снижение заболеваемости населения. Очевидно, в условиях пандемии следует осторожно относиться к показателю ввиду снижения выявляемости, сочетанности диагнозов с COVID-19. Это же относится и к оценке структуры смертности, в которой $100 \%$ стало распределяться на большее число причин. Представляется, что статистика по коронавирусу должна войти в класс инфекционных и паразитарных болезней, и это ведет к необходимости переосмысления концепции эпидемиологического перехода.

Возникшая в 2020 году пандемия коронавирусной инфекции не могла не повлиять на показатели продолжительности жизни. По сравнению с 2019 годом продолжительность жизни населения сократилась на 1,8 года, составив 71,5 года.

Как показали результаты социологического опроса, проведенного в 2020 году в Вологодской области, у населения даже в сложных эпидемиологических условиях сохраняются попустительские установки в отношении здоровья, что является дополнительным фактором риска заболеваемости и смертности во время пандемии.

Тем не менее большая часть жителей региона все же принимает меры по профилактике коронавирусной инфекции. Наиболее популярными из них стали ношение медицинской маски или респиратора, соблюдение гигиены рук, поддержка иммунитета (прием витаминов, противовирусных препаратов), отказ от посещения массовых мероприятий и нахождения в местах скопления людей, уборка, проветривание и дезинфекция помещений, соблюдение социальной дистанции.

В то же время нельзя не отметить, что стрессовая ситуация вновь спровоцировала рост потребления алкоголя. По данным Федеральной службы по регулированию алкогольного рынка розничные продажи алкогольной продукции в России выросли с 6,03 л ${ }^{9}$ на душу населения в 2019 году до 6,18 л в 2020 году; в Вологодской области - с 8,65 до 9,02 $\pi^{10}$. По результатам социологических опросов выявлено, что доля населения, воздерживающегося от употребления спиртных напитков, снизилась на 7 п. п.

В отношении россиян к массовой вакцинации от COVID-19 наблюдаются положительные изменения: повышается готовность к введению вакцины, растет доля вакцинированных. Среди главных причин отказа от введения вакцины - страх перед последствиями и побочными реакциями, а также мнение о том, что клинические испытания вакцины не окончены. В связи с этим важно формировать доверие к каналам информации, несущим объективные и полные сведения о вакцинации.

Пока рано говорить об итогах изменения демографической ситуации, вызванных пандемией, но уже сейчас очевидно, что основные тренды, сложившиеся до 2020 года, изменились. Это относится как к собственно демографическим процессам, так и к самосохранительным практикам населения, развитию здравоохранительных служб. Осмысление текущих и последующих изменений, в том числе с точки зрения их соотношения с положениями ведущих теорий, - важная задача для научного сообщества в ближайшей и среднесрочной перспективе.

\footnotetext{
9 В пересчете на литры чистого спирта (этанола).

10 Основные показатели, характеризующие рынок алкогольной продукции в 2018-2020 гг.: стат. сб. // Федеральная служба по регулированию алкогольного рынка. М., 2021. 131 с.
} 


\section{ЛИТЕРАТУРА}

1. Шабунова А.А. Здоровье и самосохранительное поведение населения в контексте COVID-19 // Coциальное пространство. 2020. T. 6. № 3. DOI: 10.15838/sa.2020.3.25.1. URL: http://socialarea-journal.ru/ article/28613

2. Российское общество и государство в условиях пандемии: социально-политическое положение и демографическое развитие Российской Федерации в 2020 году: кол. монография / Г.В. Осипов [и др.]; под ред. Г.В. Осипова [и др.]; отв. ред. В.К. Левашов. М.: Перспектива, 2020. 532 с.

3. Методические аспекты оценки заболеваемости, распространенности, летальности и смертности при COVID-19 / O.M. Драпкина [и др.]. // Кардиоваскулярная терапия и профилактика. 2020. № 19 (3). С. 302-309. DOI: 10.15829/1728-8800-2020-2585

4. Пандемия COVID-19: вызовы, последствия, противодействие: монография / А.В. Торкунов [и др.]; под ред. А.В. Торкунова, С.В. Рязанцева, В.К. Левашова; вступ. слово А.В. Торкунов. М.: Аспект Пресс, 2021. 248 с.

5. Вспышка нового инфекционного заболевания COVID-19: $\beta$-коронавирусы как угроза глобальному здравоохранению / Д.В. Горенков [и др.] // БИОпрепараты. Профилактика, диагностика, лечение. 2020. № 1. С. 6-19.

6. Новая коронавирусная инфекция (COVID-19): клинико-эпидемиологические аспекты / В.B. Никифоров [и др.] // Архивъ внутренней медицины. 2020. № 2 (52). С. 87-93.

7. Международное временное руководство по коронавирусной инфекции - 2019 (COVID-19) при беременности, в родах и в послеродовом периоде, разработанное Международной федерацией акушеров-гинекологов (FIGO) с партнерами: информация для работников здравоохранения / Л.С. Пун [и др.] // Акушерство и гинекология. Новости. Мнения. Обучение. 2020. № 2 (28). С. 8-24.

8. Синчихин С.П., Степанян Л.В., Мамиев О.Б. Новая коронавирусная инфекция и другие респираторные вирусные заболевания у беременных: клиническая лекция // Гинекология. 2020. № 2. С. 6-16.

9. Новая коронавирусная инфекция COVID-19 в практике акушера-гинеколога: обзор современных данных и рекомендаций / Е.Ю. Юпатов [и др.] // Акушерство, гинекология и репродукция. 2020. № 2. С. $148-158$.

10. Спасенников Б.А. COVID-19: уроки вакцинации // Бюл. Нац. науч.-иссл. ин-та общ. здоровья им. Н.А. Семашко. 2021. № 3. С. 116-125.

11. Горошко Н.В., Емельянова Е.К., Пацала С.В. Проблема ковид-антивакцинаторства: Россия на мировом фоне // Социальные аспекты здоровья населения. 2021. № 4. URL: https:/cyberleninka.ru/ article/n/problema-kovid-antivaktsinatorstva-rossiya-na-mirovom-fone (дата обращения 01.11.2021).

12. Влияние средств массовой информации и социальных сетей на формирование общественного мнения о вакцинации / Н.В. Орлова [и др.] // Педиатрия. Consilium Medicum. 2020. № 4. С. $17-24$. DOI: $10.26442 / 26586630.2020 .4 .20053$

13. Мурашко М.А., Драпкина О.М. Организационные аспекты вакцинации против новой коронавирусной инфекции // Национальное здравоохранение. 2021. № 2 (1). С. 5-11. URL: https://doi.org/10.47093/2713-069Х.2021.2.1.5-11

14. К вопросу о вакцинации беременных женщин в контексте пандемии COVID-19 / Е.Ю. Юпатов [и др.] // Акушерство, гинекология и репродукция. 2020. № 5. С. 656-666.

15. Шабунова А.А. Здоровье населения в России: состояние и динамика: монография. Вологда: ИСЭРТ РАН, 2010. 408 с.

16. Калачикова О.Н., Корчагина П.С. Основные тенденции самосохранительного поведения населения региона // Проблемы развития территорий. 2012 . № 5 (61). С. 72-82.

17. Демографическая ситуация и демографическое поведение населения Вологодской области: I регион. демогр. докл. / А.А. Шабунова [и др.]; под ред. А.А. Шабуновой. Вологда: ФГБУН ВолНЦ РАН, 2020. 122 с.

18. Щербакова Е.M. Заболеваемость населения России, 2019-2020 гг. // Демоскоп Weekly. 2021. № 897-898. URL: http://demoscope.ru/weekly/2021/0897/barom01.php

19. Шматова Ю.Е. Влияние COVID-19 на психическое здоровье населения (как показатель человеческого потенциала): опыт зарубежных исследований // Проблемы развития территории. 2020. № 4 (108). C. 88-108. DOI: 10.15838/ptd.2020.4.108.6 
20. Короленко А.В. Забота о здоровье в период пандемии коронавирусной инфекции: практики и их успешность // Глобальные вызовы и региональное развитие в зеркале социологических измерений: материалы VI междунар. науч.-практ. интернет-конф. (г. Вологда, 29 марта 2 апреля 2021 г.): в 2-х частях. Ч. 2. Вологда: ФГБУН ВолНЦ РАН, 2021. С. 131-135.

\section{ИНФОРМАЦИЯ ОБ АВТОРАХ}

Александра Анатольевна Шабунова - директор, доктор экономических наук, доцент, Федеральное государственное бюджетное учреждение науки «Вологодский научный центр Российской академии наук». Российская Федерация, 160014, г. Вологда, ул. Горького, д. 56a; e-mail: aas@volnc.ru

Ольга Николаевна Калачикова - кандидат экономических наук, заместитель директора по научной работе, заведующий отделом, Федеральное государственное бюджетное учреждение науки «Вологодский научный центр Российской академии наук». Российская Федерация, 160014, г. Вологда, ул. Горького, д. 56a; e-mail: onk82@yandex.ru

Александра Владимировна Короленко - научный сотрудник, Федеральное государственное бюджетное учреждение науки «Вологодский научный центр Российской академии наук». Российская Федерация, 160014, г. Вологда, ул. Горького, д. 56a; e-mail: coretra@yandex.ru

Shabunova A.A., Kalachikova O.N., Korolenko A.V.

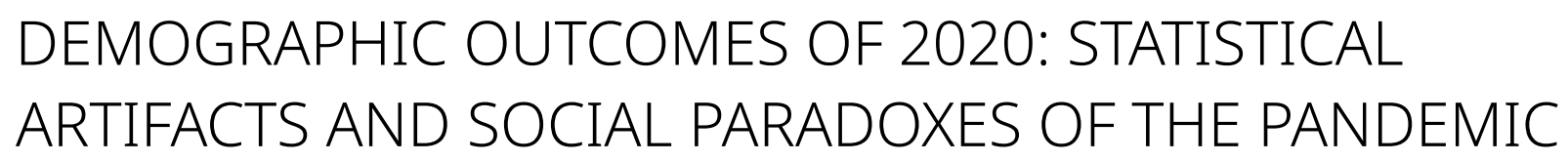

The paper presents an analysis of the main demographic indicators recorded in Russia as of the end of 2020. We have revealed that the COVID-19 pandemic contributed to the consolidation of the emerging trend of declining fertility and an increase in mortality. The contribution of coronavirus to the mortality structure was 7\%, which is higher than the percentage of deaths from respiratory, digestive, and infectious diseases and is comparable to the proportion of deaths from external causes even in the 2019 structure, which did not include coronavirus. Life expectancy decreased by 1.8 years, and the reduction in women is more pronounced than in men, which somewhat smoothed the gender disparity in overall life expectancy. A statistical artifact is the recorded decrease in the incidence of the population. It is obvious that in the conditions of a pandemic, one should be careful about this indicator due to the decrease in the detectability of diseases, the combination of diagnoses with COVID-19. The same applies to the assessment of the mortality structure, in which $100 \%$ has been allocated to a larger number of causes, although coronavirus should join the class of infectious and parasitic diseases, which requires a reconsideration of the concept of epidemiological transition. In the conditions of the pandemic, the population showed some tendency toward destruction in self-preservation behavior. In particular, the proportion of those who adhere to moderation in taking alcohol, which is often taken as a remedy for stress, has decreased. At the same time, the majority implement the recommended and regulated measures: wearing masks, gloves, social distancing, sanitary treatment. Anti-vaccination sentiments are partly due to an insufficiently complete and contradictory information campaign regarding vaccination, active stuffing of fake information.

COVID-19 pandemic, coronavirus, vaccination, morbidity, population, self-preservation behavior. 


\section{REFERENCES}

1. Shabunova A.A. Population's health and self-preservation behavior within the context of COVID-19. Sotsial'noe prostranstvo=Social Area, 2020, vol. 6, no. 3. DOI: 10.15838/sa.2020.3.25.1. URL: http://socialarea-journal.ru/article/28613 (in Russian).

2. Osipov G.V. et al. Rossiiskoe obshchestvo i gosudarstvo $v$ usloviyakh pandemii: sotsial'no-politicheskoe polozhenie i demograficheskoe razvitie Rossiiskoi Federatsii v 2020 godu: kol. monografiya [Russian Society and the State in a Pandemic: Socio-Political Situation and Demographic Development of the Russian Federation in 2020: Collective Monograph]. Moscow: Perspektiva, 2020. 532 p.

3. Drapkina O.M. Methodological aspects of assessing morbidity, prevalence, mortality and mortality in COVID-19. Kardiovaskulyarnaya terapiya i profilaktika=Cardiovascular Therapy and Prevention, 2020, no. 19 (3), pp. 302-309. DOI: 10.15829/1728-8800-2020-2585 (in Russian).

4. Torkunov A.V. et al. Pandemiya COVID-19: vyzovy, posledstviya, protivodeistvie: monografiya [COVID-19 Pandemic: Challenges, Consequences, Counteraction: Monograph]. Moscow: Aspekt Press, 2021. 248 p.

5. Gorenkov D.V. et al. Outbreak of a new infectious disease COVID-19: beta-coronaviruses as a threat to global health. BIOpreparaty. Profilaktika, diagnostika, lechenie= BIOpreparations. Prevention, Diagnosis, Treatment, 2020, no. 1, pp. 6-19 (in Russian).

6. Nikiforov V.V. et al. New coronavirus infection (COVID-19): Clinical and epidemiological aspects. Arkhiv" vnutrennei meditsiny=Archive of Internal Medicine, 2020, no. 2 (52), pp. 87-93 (in Russian).

7. Pun L.S. et al. International Interim Guidelines on Coronavirus Infection - 2019 (COVID-19) during pregnancy, childbirth and the postpartum period, developed by the International Federation of Obstetricians and Gynecologists (FIGO) with partners: information for healthcare professionals. Akusherstvo i ginekologiya. Novosti. Mneniya. Obuchenie=Obstetrics and Gynecology. News. Opinions. Training, 2020, no. 2 (28), pp. 8-24 (in Russian).

8. Sinchikhin S.P., Stepanyan L.V., Mamiev O.B. New coronavirus infection and other respiratory viral diseases in pregnant women: Clinical lecture. Ginekologiya=Gynecology, 2020, no. 2, pp. 6-16 (in Russian).

9. YupatovE.Yu.et al.New coronavirus infection COVID-19 in the practice of an obstetrician-gynecologist: A review of current data and recommendations. Akusherstvo, ginekologiya i reproduktsiya=Obstetrics, Gynecology and Reproduction, 2020, no. 2, pp. 148-158 (in Russian).

10. Spasennikov B.A. COVID-19: Vaccination lessons. Byul. Nats. nauch.-issl. in-ta obshch. zdorov'ya im. N.A. Semashko=Bulletin of N.A. Semashko National Research Institute of Public Health, 2021, no. 3, pp. 116-125 (in Russian).

11. Goroshko N.V., Emel'yanova E.K., Patsala S.V. The problem of COVID-19 anti-vaccination: Russia on a global background. Sotsial'nye aspekty zdorov'ya naseleniya=Social Aspects of Public Health, 2021, no. 4. Available at: https://cyberleninka.ru/article/n/problema-kovid-antivaktsinatorstva-rossiyana-mirovom-fone (accessed: November 1, 2021; in Russian).

12. Orlova N.V. et al. The influence of mass media and social networks on the formation of public opinion on vaccination Pediatriya. Consilium Medicum=Pediatrics. Consilium Medicum, 2020, no. 4, pp. 17-24. DOI: 10.26442/26586630.2020.4.20053 (in Russian).

13. Murashko M.A., Drapkina O.M. Organizational aspects of vaccination against the new coronavirus infection. Natsional'noe zdravookhranenie=National Healthcare, 2021, no. 2 (1), pp. 5-11. Available at: https://doi.org/10.47093/2713-069X.2021.2.1.5-11

14. Yupatov E.Yu. et al. On the issue of vaccination of pregnant women in the context of the COVID-19 pandemic. Akusherstvo, ginekologiya i reproduktsiya=Obstetrics, Gynecology and Reproduction, 2020, no. 5, pp. 656-666 (in Russian).

15. Shabunova A.A. Zdorov'e naseleniya $v$ Rossii: sostoyanie i dinamika: monografiya [Public Health in Russia: State and Dynamics: Monograph]. Vologda: ISERT RAN, 2010. 408 p.

16. Kalachikova O.N., Korchagina P.S. The main trends of self-preservation behavior of the population of the region. Problemy razvitiya territorii=Problems of Territory's Development, 2012, no. 5 (61), pp. 72-82 (in Russian).

17. Shabunova A.A. et al.Demograficheskaya situatsiya i demograficheskoe povedenie naseleniya Vologodskoi oblasti: I region. demogr. dokl. [Demographic Situation and Demographic Behavior of the Population of the Vologda Oblast: I Regional Demographic Report]. Vologda: FGBUN VolNTs RAN, 2020. 122 p. 
18. Shcherbakova E.M. Morbidity of the Russian population, 2019-2020. Demoskop Weekly=Demoscope Weekly, 2021, no. 897-898. Available at: http://demoscope.ru/weekly/2021/0897/barom01.php (in Russian).

19. Shmatova Yu.E. Impact of COVID-19 on mental health of population (as an indicator of human potential): Experience of foreign studies. Problemy razvitiya territorii=Problems of Territory's Development, 2020, no. 4 (108), pp. 88-108. DOI: 10.15838/ptd.2020.4.108.6 (in Russian).

20. Korolenko A.V. Healthcare during a pandemic of coronavirus infection: Practices and their successes. In: Global'nye vyzovy i regional'noe razvitie v zerkale sotsiologicheskikh izmerenii: sb. mat-lov VI nauch.prakt. internet-konf. [Global Challenges and Regional Development in the Mirror of Sociological Assessments: Proceedings of the 6th Research-to-Practice Conference]. Vologda, 2021. Pp. 131-135.

\section{INFORMATION ABOUT THE AUTHORS}

Aleksandra A. Shabunova - Director, Doctor of Sciences (Economics), Associate Professor, Federal State Budgetary Institution of Science "Vologda Research Center of the Russian Academy of Sciences”.56A, Gorky Street, Vologda, 160014, Russian Federation; e-mail: aas@volnc.ru

Ol'ga N. Kalachikova - Candidate of Sciences, Deputy Director for Science, Head of Department, Federal State Budgetary Institution of Science "Vologda Research Center of the Russian Academy of Sciences”. 56A, Gorky Street, Vologda, 160014, Russian Federation; e-mail:onk82@yandex.ru

Aleksandra V. Korolenko - Researcher, Federal State Budgetary Institution of Science "Vologda Research Center of the Russian Academy of Sciences”. 56A, Gorky Street, Vologda, 160014, Russian Federation; e-mail: coretra@yandex.ru 